\title{
Study on the Analysis of Main Components of Aluminum Alloy by XRF (X-Ray Fluorescence Analysis) Method
}

\author{
Yunrui Jiang, Jie Shi, Shaoqin Li \\ School of Nuclear Technology \& Automation Engineering, Chengdu University of Technology, Chengdu, China \\ Email: drwjiang@163.com
}

How to cite this paper: Jiang, Y.R., Shi, J. and Li, S.Q. (2021) Study on the Analysis of Main Components of Aluminum Alloy by XRF (X-Ray Fluorescence Analysis) Method. Open Access Library Journal, 8: e7845.

https://doi.org/10.4236/oalib.1107845

Received: August 5, 2021

Accepted: September 6, 2021

Published: September 9, 2021

Copyright $\odot 2021$ by author(s) and Open Access Library Inc.

This work is licensed under the Creative Commons Attribution International License (CC BY 4.0).

http://creativecommons.org/licenses/by/4.0/

\begin{abstract}
Aluminum alloy has low density, good plasticity, and high strength. It has a large number of applications in many fields. The performance of aluminum alloy is closely related to its alloy composition. The rapid and accurate determination of the content of various elements in aluminum alloy is important for its production and processing. The experiment is based on the energy dispersive X-ray fluorescence analysis method, and analyzes the main elements in the aluminum alloy samples with different composition. The best working mode and the best measurement time of different elements are determined among the partitions. The data measured in the experiment were compared and analyzed by using one-variable, two-variable, and three-variable fitting methods, and the best multiple fitting method for different elements was determined. After ternary fitting, the average absolute errors for $\mathrm{Al}, \mathrm{Mg}$, and Si are $0.040 \%, 0.027 \%$, and $0.007 \%$, respectively, and the average relative errors are $0.040 \%, 2.111 \%$, and $0.469 \%$, respectively; after binary fitting, the average absolute errors for $\mathrm{Cu}$ and $\mathrm{Zn}$ are $0.001 \%$ and $0.001 \%$, and the average relative errors are $0.061 \%$ and $0.070 \%$. The average absolute errors of $\mathrm{Zn}$ are $0.001 \%$ and $0.001 \%$, and the average relative errors are $0.061 \%$ and $0.070 \%$, respectively. The experimental results prove that the XRF method can be applied to the accurate measurement of the main components of aluminum alloy.
\end{abstract}

\section{Subject Areas}

Nuclear Technology and Application

\section{Keywords}

XRF, Aluminum Alloy, Matrix Effect, Multiple Regression Method 


\section{Introduction}

With the rapid development of the global market economy in recent years, aluminum and its polymer alloy materials have been used in aerospace, vehicle manufacturing, mechanical processing, electronic appliances and other fields with their excellent properties such as oxidation resistance, easy repeat processing, and recyclability. It has been widely used in the world and has developed into the world's second-largest metal material in use after steel. The utilization rate is increasing year by year. At present, my country has become the world's largest aluminum alloy producer and consumer.

The physical and chemical properties of aluminum alloys are closely related to the material composition of the alloys. The accurate quantitative analysis of its composition, structure, and properties plays an important role in guiding the production and processing of aluminum alloys. Compared with the classical chemical methods commonly used in alloy composition analysis, the XRF analysis method has the characteristics of fast and accurate, and can realize on-site non-destructive analysis. The experiment uses the XRF method to analyze the main elements in the aluminum alloy and achieves better results. It is expected to provide reference for XRF method in rapid detection of aluminum alloy industrial production.

\section{Basic principles}

According to Moseley's law, the square of the atomic number is proportional to the energy of the characteristic ray [1] [2]. If the atomic number is different, the characteristic ray generated after being excited will be different. The purpose of the X-ray fluorescence quantitative analysis method is to calculate the content of the element to be measured in the sample through the count rate obtained by the measurement. Therefore, one can first determine the material composition of the sample, calculate the proportional coefficient, and then calculate the content of the element to be measured according to the counting rate:

$$
W_{k}=\frac{\mu_{0}+\mu_{k}}{K I_{0}} \cdot I_{k} \text {. }
$$

\section{Apparatus and Sample Preparation}

\subsection{Abbreviations and Acronyms}

The instrument used in this experiment is the desktop integrated XRF energy spectrum analyzer Epsilon 1 produced by Malvern PANalytical, the Netherlands. It adopts X-ray tube with maximum voltage of $50 \mathrm{kV}$ and maximum current of $500 \mu \mathrm{A}, \mathrm{Ag}$ anode, and SDD (Silicon Drift Semiconductor Detector). The measurement element range is $\mathrm{Na}-\mathrm{Am}$, the resolution is $135 \mathrm{eV}(\mathrm{Mg}-\mathrm{Ka})$, and the detection limit is $1 \mathrm{ppm}-100 \%$. Use USB and network connections to use standard computer peripherals for extended use, application development, and fixed operators.

The main analysis elements in this experiment are $\mathrm{Al}, \mathrm{Si}, \mathrm{Mg}, \mathrm{Cu}, \mathrm{Zn}$, so it is 
established after selecting the elements, so the $\mathrm{Na}-\mathrm{Si}$ mode (applicable elements range from $\mathrm{Na}$ to $\mathrm{Si}$ ) and $\mathrm{Ni}-\mathrm{Mo}$ mode are established after selecting the elements on the instrument (The applicable elements range from $\mathrm{Ni}$ to $\mathrm{Mo}$ ), and then the best tube pressure, tube flow and best time are measured for different modes [3].

According to previous experiments, the optimal tube pressure of $\mathrm{Na}-\mathrm{Si}$ mode is $17 \mathrm{kV}$, the best tube flow is $75 \mu \mathrm{A}$, the best measurement time is $600 \mathrm{~s}$, the best filter is AL200; the best tube pressure of Ni-Mo mode is $46 \mathrm{kV}$, The best tube flow is $98 \mu \mathrm{A}$, the best measurement time is $1200 \mathrm{~s}$, and the best filter is AL200 (Built in the instrument).

All relevant parameters of the instrument are obtained from the same series of pre experiments, due to space constraints, only the final results are listed here.

\subsection{Sample Preparation}

The solid samples are cylindrical and the size is: $\Phi 40 \mathrm{~mm} \times 20 \mathrm{~mm}$ (height). Since the surface finish of the metal sample directly affects the X-ray fluorescence intensity, this effect is related to the element to be measured, so when measuring, the end of the sample without characters is polished with a lathe and then wiped clean with medical cotton.

\section{Experimental Results and Analysis}

There are different series of aluminum alloys, and each series of aluminum alloys contains other elements besides aluminum [4] [5]. In addition to the analysis of $\mathrm{Al}$, this experiment mainly analyzes the elements of $\mathrm{Si}, \mathrm{Mg}, \mathrm{Cu}$, and $\mathrm{Zn}$ in the aluminum alloy. The $\mathrm{K}$ absorption limit energy and Ka characteristic energy of each element are shown in Table 1.

In order to weaken the influence of the matrix effect, the five main elements of $\mathrm{Al}, \mathrm{Si}, \mathrm{Mg}, \mathrm{Cu}$, and $\mathrm{Zn}$ were fitted with one element, two elements and three elements respectively [6] [7] [8]. Aiming at the characteristics that the characteristic energies of $\mathrm{Al}, \mathrm{Mg}$, and $\mathrm{Si}$ are close to the absorption limit energy and will affect each other, the Al-Mg-Si ternary fitting calculation results with better correction effects are selected. The results and analysis are shown in Table 2-4.

For $\mathrm{Cu}$ and $\mathrm{Zn}$, considering the influence of the higher content of $\mathrm{Al}$ in the sample, the $\mathrm{Al}-\mathrm{Cu}$ and $\mathrm{Al}-\mathrm{Zn}$ binary fitting calculation results with better correction effect are selected. The results and analysis are shown in Table 5.

Table 1. Absorption limit energy of each main element in aluminum alloy.

\begin{tabular}{ccc}
\hline element & K absorption limit energy $(\mathrm{E} / \mathrm{keV})$ & $\mathrm{K}_{\alpha}$ characteristic energy $(\mathrm{E} / \mathrm{keV})$ \\
\hline $\mathrm{Mg}$ & 1.303 & 1.254 \\
$\mathrm{Al}$ & 1.559 & 1.487 \\
$\mathrm{Si}$ & 1.838 & 1.740 \\
$\mathrm{Cu}$ & 8.980 & 8.047 \\
$\mathrm{Zn}$ & 9.660 & 8.638 \\
\hline
\end{tabular}


Table 2. Ternary fitting results of Al.

\begin{tabular}{|c|c|c|c|c|}
\hline \multicolumn{5}{|c|}{$\mathrm{Al}$} \\
\hline $\begin{array}{l}\text { Serial } \\
\text { number }\end{array}$ & $\begin{array}{l}\text { Recommended } \\
\text { value }\end{array}$ & $\begin{array}{l}\text { Analysis } \\
\text { value }\end{array}$ & $\begin{array}{l}\text { Absolute } \\
\text { error }\end{array}$ & $\begin{array}{l}\text { Relative } \\
\text { error (\%) }\end{array}$ \\
\hline A3 & 90.086 & 98.062 & 0.079 & 0.080 \\
\hline A9 & 96.060 & 94.494 & -0.016 & -0.010 \\
\hline A13 & 96.275 & 97.873 & 0.017 & 0.010 \\
\hline A17 & 87.699 & 82.849 & -0.055 & -0.060 \\
\hline Ave & 95.084 & 98.840 & 0.040 & 0.040 \\
\hline
\end{tabular}

Table 3. Ternary fitting results of $\mathrm{Mg}$.

\begin{tabular}{|c|c|c|c|c|}
\hline \multicolumn{5}{|c|}{$\mathrm{Mg}$} \\
\hline $\begin{array}{l}\text { Serial } \\
\text { number }\end{array}$ & $\begin{array}{l}\text { Recommended } \\
\text { value }\end{array}$ & $\begin{array}{c}\text { Analysis } \\
\text { value }\end{array}$ & $\begin{array}{c}\text { Absolute } \\
\text { error }\end{array}$ & $\begin{array}{l}\text { Relative } \\
\text { error (\%) }\end{array}$ \\
\hline $\mathrm{A} 3$ & 1.202 & 1.269 & 0.056 & 4.650 \\
\hline A9 & 2.269 & 2.246 & -0.010 & -0.440 \\
\hline A13 & 1.096 & 1.110 & 0.012 & 1.120 \\
\hline A17 & 1.571 & 1.571 & -0.038 & -2.300 \\
\hline Ave & 1.293 & 1.293 & 0.027 & 2.111 \\
\hline
\end{tabular}

Table 4. Ternary fitting results of Si.

\begin{tabular}{|c|c|c|c|c|}
\hline \multicolumn{5}{|c|}{$\mathrm{Si}$} \\
\hline $\begin{array}{c}\text { Serial } \\
\text { number }\end{array}$ & $\begin{array}{l}\text { Recommended } \\
\text { value }\end{array}$ & $\begin{array}{l}\text { Analysis } \\
\text { value }\end{array}$ & $\begin{array}{l}\text { Absolute } \\
\text { error }\end{array}$ & $\begin{array}{l}\text { Relative } \\
\text { error (\%) }\end{array}$ \\
\hline $\mathrm{A} 1$ & 1.702 & 1.690 & -0.007 & -0.410 \\
\hline A4 & 2.839 & 2.848 & 0.003 & 0.110 \\
\hline A5 & 1.328 & 1.328 & -0.010 & -0.710 \\
\hline A6 & 1.383 & 1.395 & 0.009 & 0.620 \\
\hline Ave & 1.567 & 1.579 & 0.007 & 0.469 \\
\hline
\end{tabular}

Table 5. The binary fitting results of $\mathrm{Cu}$ and $\mathrm{Zn}$.

\begin{tabular}{|c|c|c|c|c|c|c|c|c|}
\hline \multicolumn{5}{|c|}{$\mathrm{Cu}$} & \multicolumn{4}{|c|}{$\mathrm{Zn}$} \\
\hline $\begin{array}{c}\text { Serial } \\
\text { number }\end{array}$ & $\begin{array}{l}\text { Recommen-ded } \\
\text { value }\end{array}$ & $\begin{array}{l}\text { Analysis } \\
\text { value }\end{array}$ & $\begin{array}{l}\text { Absolut } \\
\text { e error }\end{array}$ & $\begin{array}{l}\text { Relative } \\
\text { error (\%) }\end{array}$ & $\begin{array}{l}\text { Recommen-ded } A \\
\text { value }\end{array}$ & $\begin{array}{c}\text { Analysis } \\
\text { value }\end{array}$ & $\begin{array}{l}\text { Absolut } \\
\text { e error }\end{array}$ & $\begin{array}{l}\text { Relative } \\
\text { error (\%) }\end{array}$ \\
\hline A1 & 4.371 & 4.372 & 0.000 & 0.000 & 0.039 & 0.039 & 0.001 & 1.400 \\
\hline A2 & 0.081 & 0.081 & 0.001 & 0.980 & 0.005 & 0.005 & -0.000 & -2.680 \\
\hline A3 & 0.081 & 0.081 & -0.002 & -1.790 & 0.004 & 0.004 & -0.000 & -5.570 \\
\hline A5 & 0.260 & 0.260 & 0.001 & 0.390 & 0.100 & 0.010 & -0.003 & -2.750 \\
\hline A6 & 1.777 & 1.776 & -0.001 & -0.030 & 5.792 & 5.792 & 0.000 & 0.000 \\
\hline Ave & 1.314 & 1.315 & 0.001 & 0.061 & 0.994 & 1.000 & 0.001 & 0.070 \\
\hline
\end{tabular}




\section{Conclusions}

The experiment uses an energy dispersive $\mathrm{X}$-ray fluorescence instrument to analyze the five main elements of $\mathrm{Al}, \mathrm{Si}, \mathrm{Mg}, \mathrm{Cu}$, and $\mathrm{Zn}$ in aluminum alloys. The experimental measurement is carried out by setting the measurement mode between different regions of the absorption limit energy of different elements, and obtains the following results:

1) Considering the peak-to-back ratio, counting rate and measurement time, the relevant parameters of the Na-Si mode and Ni-Mo mode are determined.

2) The basic mathematical models of X-ray fluorescence for five elements of $\mathrm{Al}, \mathrm{Mg}, \mathrm{Si}, \mathrm{Cu}$ and $\mathrm{Zn}$ have been established.

3) Using the multiple regression method to establish matrix effect correction formulas for $\mathrm{Al}$ and $\mathrm{Mg}, \mathrm{Si}, \mathrm{Cu}$, and $\mathrm{Zn}$, and compare the calculation results of different parameters, it is concluded that the ternary fitting is used for Al. It is concluded that the correction effect of $\mathrm{Mg}$ and $\mathrm{Si}$ is better, and the correction effect of the binary fitting is better for $\mathrm{Cu}$ and $\mathrm{Zn}$.

Energy dispersive X-ray fluorescence instrument has the advantages of fast, non-destructive, convenient, and high sensitivity, and can be competent for the analysis of aluminum alloy samples.

\section{Acknowledgements}

Thanks to the Key Laboratory of Geoscience and nuclear technology of Chengdu University of Technology for its equipment support and also for my partners Shi and Zhou for their technical assistance during the experiment.

\section{Conflicts of Interest}

The authors declare no conflicts of interest.

\section{References}

[1] Šatović, D., Desnica, V. and Fazinić, S. (2013) Use of Portable X-Ray Fluorescence Instrument for Bulk Alloy Analysis on Low Corroded Indoor Bronzes. Spectrochimica Acta Part B: Atomic Spectroscopy, 7, 7-13. https://doi.org/10.1016/j.sab.2013.08.007

[2] Matthew Stauffer (2017) How to Use XRF Testing Instruments to Accurately Measure Zinc Nickel. Products Finishing, 10, 38-39.

[3] Recknagel, S., Noack, S. and Steiger, T. (2010) International Comparability of Determination of Mass Fractions of Chromium, Copper, Iron, Manganese and Zinc in Aluminium Alloy: Comité Consultatif pour la Quantité de Matière key comparison K42. Accreditation and Quality Assurance, 7, 401-407. https://doi.org/10.1007/s00769-010-0641-5

[4] Jin, C.Z. (2011) Quantitative Analysis of $\mathrm{Cu}$ Alloy Series using Hand Held XRF Device. Journal of Korean Institute of Information Technology, 11, 89-95.

[5] Anonymous (2008) On-line XRF for Fast Alloy Analysis. Quality, 4, 32.

[6] Makjanić, J., Orlić, I. and Valković, V. (2005) Elemental Analysis of Alloys by XRF. Akadémiai Kiadó, Co-Published with Springer Science + Business Media B.V., 
Formerly Kluwer Academic Publishers B. V, 1, 91. https://doi.org/10.1007/BF02036328

[7] Recknagel, S. and Matschat, R. (2010) Analysis of a Copper Alloy: Comité Consultatif pour la Quantite de Matière (CCQM) Pilot Study P76 International Intercomparison. Accreditation and Quality Assurance, 8, 433-441.

https://doi.org/10.1007/s00769-008-0393-7

[8] Weise, H.-P., Görner, W. and Hedrich, M. (2001) Determination of Elements by Nuclear Analytical Methods. Fresenius' Journal of Analytical Chemistry, 1, 8-14. https://doi.org/10.1007/s002160000626 